New Drugs for Asthma, Allergy and COPD 


\section{Progress in Respiratory Research}

Vol. 31

Series Editor

Chris T. Bolliger, Cape Town

KARGER $\begin{aligned} & \text { Basel } \cdot \text { Freiburg } \cdot \text { Paris } \cdot \text { London } \cdot \text { New York } \\ & \text { New Delhi } \cdot \text { Bangkok } \cdot \text { Singapore } \cdot \text { Tokyo } \text { Sydney }\end{aligned}$ 


\section{New Drugs for Asthma, Allergy and COPD}

Volume Editors Trevor T. Hansel, London

Peter J. Barnes, London

195 colour figures and 72 tables, 2001

KARGER $\begin{aligned} & \text { Basel } \cdot \text { Freiburg } \cdot \text { Paris } \cdot \text { London } \cdot \text { New York } \cdot \\ & \text { New Delhi } \cdot \text { Bangkok } \cdot \text { Singapore } \cdot \text { Tokyo } \cdot \text { Sydney }\end{aligned}$ 


\section{Trevor T. Hansel}

Clinical Studies Unit

National Heart and Lung Institute

Imperial College

London (UK)

\section{Peter J. Barnes}

Department of Thoracic Medicine National Heart and Lung Institute Imperial College

London (UK)

New drugs for asthma, allergy and COPD / volume editors, Trevor T. Hansel, Peter J. Barnes.

p. ; cm. - (Progress in respiratory research, ISSN 1422-2140; vol. 31)

Includes bibliographical references and indexes.

ISBN 3805568622 (alk paper : hard cover)

1. Respiratory agents. 2. Antiasthmatic agents. 3. Lungs - Diseases, Obstructive - Chemotherapy.

I. Hansel, T.T. (Trevor T.), 1956- II. Barnes, Peter J., 1946- III. Series.

[DNLM: 1. Asthma-drug therapy. 2. Anti-Asthmatic Agents - therapeutic use. 3. Hypersensitivity - drug therapy.

4. Lung Diseases, obstructive - drug therapy. WF 553 N5321 2001]

RM388.N49 2001

$615^{\prime} .72-\mathrm{dc} 21$

00-050644

Bibliographic Indices. This publication is listed in bibliographic services, including Current Contents ${ }^{\circledR}$ and Index Medicus.

Drug Dosage. The authors and the publisher have exerted every effort to ensure that drug selection and dosage set forth in this text are in accord with current recommendations and practice at the time of publication. However, in view of ongoing research, changes in government regulations, and the constant flow of information relating to drug therapy and drug reactions, the reader is urged to check the package insert for each drug for any change in indications and dosage and for added warnings and precautions. This is particularly important when the recommended agent is a new and/or infrequently employed drug.
All rights reserved. No part of this publication may be translated into other languages, reproduced or utilized in any form or by any means, electronic or mechanical, including photocopying, recording, microcopying, or by any information storage and retrieval system, without permission in writing from the publisher.

CC Copyright 2001 by S. Karger AG,

P.O. Box, CH-4009 Basel (Switzerland)

www.karger.com

Printed in Switzerland on acid-free paper by

Reinhardt Druck, Basel

ISBN 3-8055-6862-2, ISSN 1422-2140 


\section{Contents}

\section{Foreword}

IX Preface

General Aspects

2 The Need for New Therapy

Barnes, P.J.; Hansel, T.T. (NHLI, Imperial College, London)

6 Current Therapy for Asthma

Barnes, P.J. (NHLI, Imperial College, London)

11 Current Therapy for COPD

Pauwels, R. (Ghent University Hospital, Ghent)

15 Pharmacogenetics

Hall, I.P. (University Hospital, Nottingham); Hansel, T.T.

(NHLI, Imperial College, London)

20 Delivery of Biologics to the Lung

Cipolla, D.; Farr, S.; Gonda, I.; Otulana, B.

(Aradigm Corporation, Hayward, Calif.)

24 Immunopathology: Comparison of COPD and Asthma

Jeffery, P.K. (NHLI, Imperial College, London)

30 Monitoring Lung Function

Pride, N. (NHLI, Imperial College, London)

35 Airway Hyperresponsiveness

Sterk, P.J. (Leiden University Medical Centre, Leiden)

39 Airways Remodelling

Holgate, S.T.; Davies, D.E. (University of Southampton, Southampton)

44 Exhaled Breath Analysis

Kharitonov, S.A.; Barnes, P.J. (NHLI, Imperial College, London)

48 Clinical Studies on New Drugs

Hansel, T.T.; Barnes, P.J. (NHLI, Imperial College, London)

Bronchodilators

54 Bronchodilators: An Overview

Anderson, G.P. (University of Melbourne, Melbourne);

Rabe, K.F. (Leiden University Center, Leiden)

60 Long-Acting $\boldsymbol{\beta}_{\mathbf{2}}$-Agonists

Johnson, M.; Hagan, G.W.E. (GlaxoWellcome, Uxbridge)
64 Single-Isomer $\beta$-Agonists

Handley, D.A. (Sepracor, Marlborough, Mass.); Morley, J.

(Haldane Research, Huntingdon); Nelson, H.S. (National Jewish

Medical and Research Center, Denver, Colo.)

68 Dual $D_{2}$ Dopamine Receptor and $\beta_{2}$-Adrenoceptor Agonists for the Modulation of Sensory Nerves in COPD

Newbold, P.; Jackson, D.M.; Young, A.; Dougall, I.G.; Ince, F.; Rocchiccioli, K.M.S.; Holt, P.R. (AstraZeneca, Loughborough)

72 Anticholinergics: Tiotropium

Disse, B.; Witek, T.J., Jr. (Boehringer Ingelheim, Ingelheim and Ridgefield, Conn.)

77 Potassium Channel Openers

Agents for the Treatment of Airway Hyperreactivity Fozard, J.R.; Manley, P.W. (Novartis Pharma Ltd., Basel)

81 Urodilatin

Forssmann, K.; Meyer, M.; Forssmann, W.G. (CardioPep Pharma GmbH and IPF PharmaCeuticals GmbH, Hannover)

Steroids

86 Steroids: An Overview

Dahl, R.; Nielsen, L.P. (University of Aarhus, Aarhus)

91 Ciclesonide: An On-Site-Activated Steroid Dietzel, K.; Engelstätter, R.; Keller, A. (Byk Gulden Pharmaceuticals, Konstanz)

94 Soft Steroids

Axelsson, B.; Brattsand, R. (AstraZeneca, Lund)

98 Dissociated Steroids

Brown, T.J.; Belvisi, M.G.; Foster, M.L. (Aventis Pharmaceuticals, Dagenham)

102 Oestradiol Metabolites

Effects on Airway Remodelling

Stewart, A.G.; Vlahos, R.; Fernandes, D.J.; Hughes, R.A. (University of Melbourne, Melbourne)

Leukotriene Inhibitors

108 Leukotriene Inhibitors: An Overview

O'Byrne, P.M. (McMaster University, Hamilton); Drazen, J.M. (Harvard Medical School, Boston, Mass.) 
111 Cysteinyl Leukotriene Antagonists McMillan, R.M. (AstraZeneca, Macclesfield)

115 5-Lipoxygenase Inhibitors Dahlén, S.-E. (Karolinska Institutet, Stockholm)

121 LTB $_{4}$ Antagonism

Jennewein, H.M.; Anderskewitz, R.; Meade, C.J.; Pairet, M.; Birke, F. (Boehringer Ingelheim, Ingelheim)

Mediator Inhibitors and Agonists

$128 \mathrm{H}_{\mathbf{1}}$-Antihistamines

De Vos, C.; Rihoux, J.P. (UCB Pharma SA, Brussels)

133 Histamine $\mathrm{H}_{3}$ Antagonists

McLeod, R.L.; Egan, R.W.; Cuss, F.M. (Schering-Plough, Kenilworth, N.J.); Bolser, D.C. (University of Gainesville, Gainesville, Fla.).; Hey, J.A. (Schering-Plough, Kenilworth, N.J.)

137 Kinin Receptor Antagonists

Meini, S.; Maggi, C.A. (Menarini Ricerche SpA, Florence)

141 Endothelin Antagonists

Hay, D.W.P.; Compton, C.H. (SmithKline Beecham Pharmaceuticals, King of Prussia, Pa., and Harlow)

145 Tachykinin Antagonists

Hay, D.W.P. (SmithKline Beecham Pharmaceuticals, King of Prussia, $\mathrm{Pa}$.)

151 Antioxidants

MacNee, W. (University of Edinburgh, Edinburgh)

156 Selective iNOS Inhibitors

Manning, P.T.; Thompson, J.M. (Searle, St. Louis, Mo., and Skokie, Ill.); Currie, M.G. (Sepracor Inc., Marlborough, Mass.)

160 Mucus Regulation

Rogers, D.F. (NHLI, Imperial College, London)

165 P2Y Receptor Agonists

Role in Mucosal Hydration and Mucociliary Clearance Pendergast, W.; Evans, R. (Inspire Pharmaceuticals, Inc., Durham, N.C.)

Protease Inhibitors

170 Tryptase Inhibition

Clark, J.M.; Van Dyke, R.E.; Kurth, M.C. (Axys

Pharmaceuticals, Inc., S. San Francisco, Calif.)

173 Neutrophil Elastase Inhibitors

Smith, R.A. (GlaxoWellcome, Stevenage); Stockley, R.A. (Queen Elizabeth Hospital, Birmingham); Hodgson, S.T. (GlaxoWellcome, Stevenage)

177 Macrophage Metalloelastase Inhibitors

Martin, R.L. (Roche Bioscience, Palo Alto, Calif.); Shapiro, S.D.

(Washington University, St. Louis, Mo.); Tong, S.E.;

Van Wart, H.E. (Roche Bioscience, Palo Alto, Calif.)
Allergen- and lgE-Directed Therapies

182 Allergen, IgE and Mast-Cell-Directed Responses: An Overview

Larché, M.; Kay, A.B. (NHLI, Imperial College, London)

186 Allergen Immunotherapy

Wilson, D.R.; Durham, S.R. (NHLI, Imperial College, London)

191 Peptide Immunotherapy

Oldfield, W.L.G.; Kay, A.B.; Larché, M. (NHLI, Imperial College, London)

195 Recombinant Allergens

Valenta, R.; Kraft, D. (University of Vienna, Vienna)

201 Anti-lgE Antibody

Boushey, H.A. (University of California, San Francisco, Calif.);

Fick, R. (Genentech, Inc., S. San Francisco, Calif.);

Fahy, J.V. (University of California, San Francisco, Calif.)

206 CD23

Conrad, D.H. (Virginia Commonwealth University, Richmond, Va.)

T Cell Immunomodulation

212 T Cell Immunomodulation: An Overview Koulis, A.; Robinson, D.S. (NHLI, Imperial College, London)

217 Costimulatory Molecules in T Cell Activation Coyle, A.J.; Gutierrez-Ramos, J.-C. (Millennium Pharmaceuticals Inc., Cambridge, Mass.)

222 GATA-3: A Th2-Selective Target Ray, A.; Ray, P. (Yale University, New Haven, Conn.)

226 Mycobacterial Immunization Agents to Limit Asthma Hopkin, J.M. (University of Wales, Swansea)

229 CpG Oligodeoxynucleotides Kline, J.N.; Krieg, A.M. (University of Iowa, Iowa City, Iowa, and Coley Pharmaceutical Group, Wellesley, Mass.)

233 CD8 T Cells: Potential Therapeutic Targets? Out, T.A. (Academic Medical Center and CLB Sanquin Blood Supply Foundation, Amsterdam); de Pater-Huijsen, F.L.; Jansen, H.M. (Academic Medical Center, Amsterdam); Corrigan, C.J. (Guy's, King's and St. Thomas' School of Medicine, London)

237 Macrocyclic Immunosuppressants

Keller, T.H.; Hersperger, R.; Della Cioppa, G. (Novartis, Horsham and Basel)

Cytokine-Directed Therapy

242 Cytokines: An Overview Chung, K.F. (NHLI, Imperial College, London)

247 TNF Antagonism

McDonnell, N.D.; Abbott, N.M.; Mohler, K.M. (Immunex Corp., Seattle, Wash.); Hansel, T.T. (NHLI, Imperial College, London); Kips, J.C. (Ghent University Hospital, Ghent) 
251 GM-CSF Antagonists

Williams, W.V. (SmithKline Beecham, Philadelphia, Pa.)

256 Interleukin-4 Antagonism

Borish, L. (University of Virginia, Charlottesville, Va.); Agosti, J.M. (Immunex Corporation, Seattle, Wash.)

260 Interleukin-13 Antagonism

Donaldson, D.D. (Wyeth-Ayerst, Andover, Mass.); Elias, J.A. (Yale University, New Haven, Conn.); Wills-Karp, M. (Johns Hopkins University, Baltimore, Md.)

265 Interleukin-5 Antagonism

Leckie, M.J. (NHLI, Imperial College, London); Walker, C. (Novartis Research Centre, Horsham)

269 Interleukin-10

Narula, S.; Cuss, F. (Schering-Plough Research Institute, Kenilworth, N.J.)

274 Interleukin-12, Interleukin-18 and Interferon-V Bryan, S. (NHLI, Imperial College, London); Kobayashi, M. (Wyeth-Ayerst, Andover, Mass.); Sur, S. (University of Texas, Galveston, Tex.)

Chemokine Receptor Inhibition

280 Chemokines: An Overview

Sabroe, I.; Williams, T.J. (Imperial College, South Kensington)

284 Chemokine Receptors on Th1 and Th2 Cells

Sinigaglia, F. (Roche Milano Ricerche, Milan); Fabbri, L.M. (University of Modena, Modena); D'Ambrosio, D. (Roche Milano Ricerche, Milan)

288 CCR-3 Antagonists

Bryan, S.A. (NHLI, Imperial College, London); Ponath, P.D. (LeukoSite, Inc., Cambridge, Mass.); Wilhelm, R.S. (Roche Bioscience, Palo Alto, Calif.)

293 Interleukin-8 Receptor (CXCR2) Antagonists Sarau, H.M.; Widdowson, K.L.; Palovich, M.R.; White, J.R.; Underwood, D.C.; Griswold, D.E. (SmithKline Beecham Pharmaceuticals, King of Prussia, Pa.)

Adhesion Molecule Inhibitors

298 Adhesion Molecule Antagonism: An Overview Bochner, B.S. (Johns Hopkins University, Baltimore, Md.)

302 Small-Molecule VLA-4 Antagonists Adams, S.P.; Lobb, R.R. (Biogen Inc., Cambridge, Mass.)

306 Selectin Antagonists Therapeutics for Airway Inflammation Berens, K.L.; Vanderslice, P.; Dupré, B.; Dixon, R.A.F. (Texas Biotechnology Corporation, Houston, Tex.)

310 ICAM-1 and VCAM-1 Antagonists Richards, I.M.; Slatter, V.K. (Pharmacia Corporation, Kalamazoo, Mich.)
Inhibition of Cell Signalling

316 Eosinophil G-Protein-Coupled Receptor Signalling: An Overview

Lindsay, M.A.; De Souza, P.M.; Lynch, O.T.; Giembycz, M.A. (NHLI, Imperial College, London)

321 Phosphodiesterase 4 Inhibitors

Torphy, T.J.; Compton, C.H.; Marks, M.J. (SmithKline Beecham, King of Prussia, Pa., Harlow, and Collegeville, Pa.); Sturton, G. (Bayer plc, Slough)

Therapies Acting on Transcription

328 Therapies Acting on Transcription: An Overview Caramori, G.; Adcock, I.M. (NHLI, Imperial College, London)

332 Chromatin Modification

Urnov, F.D.; Wolffe, A.P. (Sangamo Biosciences, Richmond, Calif.)

337 Activator Protein-1 and Nuclear Factor-Kappa B Bennett, B.L.; Manning, A.M. (Signal Pharmaceuticals, Inc., San Diego, Calif.)

342 Inhibition of p38 MAP Kinase

Underwood, D.C.; Griswold, D.E. (SmithKline Beecham Pharmaceuticals, King of Prussia, $\mathrm{Pa}$.)

346 STAT6

Role in IL-4-Mediated Signaling

Schaefer, G.; Venkataraman, C.; Schindler, U. (Tularik, Inc., S. San Francisco, Calif.)

350 Retinoids

Belloni, P.N. (Roche Bioscience, Palo Alto, Calif.)

Genetic Therapy

358 Asthma and COPD Genetics and Genomics: An Overview

Morrison, J.F.J. (AstraZeneca, Macclesfield)

361 Respirable Antisense Oligonucleotides

Nyce, J.W. (EpiGenesis Pharmaceuticals, Inc., Princeton, N.J.)

365 Antisense Therapy

Bennett, C.F. (Isis Pharmaceuticals, Inc., Carlsbad, Calif.)

370 Ribozyme Therapy

Sandberg, J.A.; Lee, P.A.; Usman, N. (Ribozyme

Pharmaceuticals, Inc., Boulder, Colo.)

374 Gene Therapy

Kolb, M.; Gauldie, J. (McMaster University, Hamilton)

379 Author Index

381 Subject Index

388 Abbreviations 


\section{Foreword}

For this first volume written in the new millennium I decided to go for a book on new drugs for asthma and COPD which would be of interest to many doctors involved in the treatment of these diseases. When looking for someone to edit this 31 st volume of the series 'Progress in Respiratory Research' I was fortunate enough to get Trevor T. Hansel and Peter J. Barnes interested. During our initial meeting in Madrid in September 1999, I told them that I would be interested in 'real' progress in drug research and not in a book which would be outdated by the time it is printed. After some moments of hesitation they said that this would mean involvement of a lot of researchers from pharmaceutical companies together with clinicians, and what about conflicts of interest!? When I replied that this mix represented the real world, and was exactly what I wanted, they promised to think about it and get back to me. After a short period they announced their concept of putting together a book with 80 ultra con- cise chapters addressing every possible drug from established, commercially available substances to compounds in their early testing phase.

The final product exceeds my wildest expectations. Trevor and Peter managed to rally a fantastic group of authors, whose names reflect a 'who's who' in the field. The chapters rarely exceed 4 printed pages, limiting the information to the essentials. The book is lavishly illustrated with 72 tables and 195 colour figures, which have been edited by Trevor to obtain uniformity; that means an eosinophil looks the same in every figure of the book!

This book will serve as a key reference of current and future developments in the treatment of asthma, allergy, and COPD; it will appeal to the practising physician as well as to the pulmonologist with a special pharmacological interest. Get it and enjoy it!

Chris T. Bolliger Series Editor 


\section{Preface}

Asthma and COPD have now become amongst the commonest diseases in the world, and both are increasing. There have been major advances in our understanding of asthma and significant improvement in asthma management, particularly with the early and more widespread use of inhaled corticosteroids. Yet, despite effective therapy for asthma, there is a pressing need for new and more specific therapies that control the disease or even cure the underlying disease process. Progress in understanding and treating COPD has been much slower, mainly because the disease has been relatively neglected. None of the treatments available today prevent the relentless progression of COPD and there is an urgent need to develop novel approaches.

The aim of this book is to offer a state-of-the-art description of the exciting progress in research and development that is being made with new therapies for asthma, allergy and COPD. We are very aware that many large tomes that contain review chapters by leading scientific and clinical authorities are already available on allergic and respiratory diseases. On this basis, our major intention was to link the biotechnology and pharmaceutical industry with academic and clinical opinion. In order to develop better therapies, we rely on this partnership, since the modern-day reality is that novel drug discovery and production generally occur from within the industry.

We have been amazed by the enthusiastic response from our colleagues in the pharmaceutical industry in providing as much information as they can about early developments with their novel potential therapies. By way of introduction to these contributions, we have overviews written by leading academic clinical scientists. With over 200 authors, and a total of 80 chapters, we hope

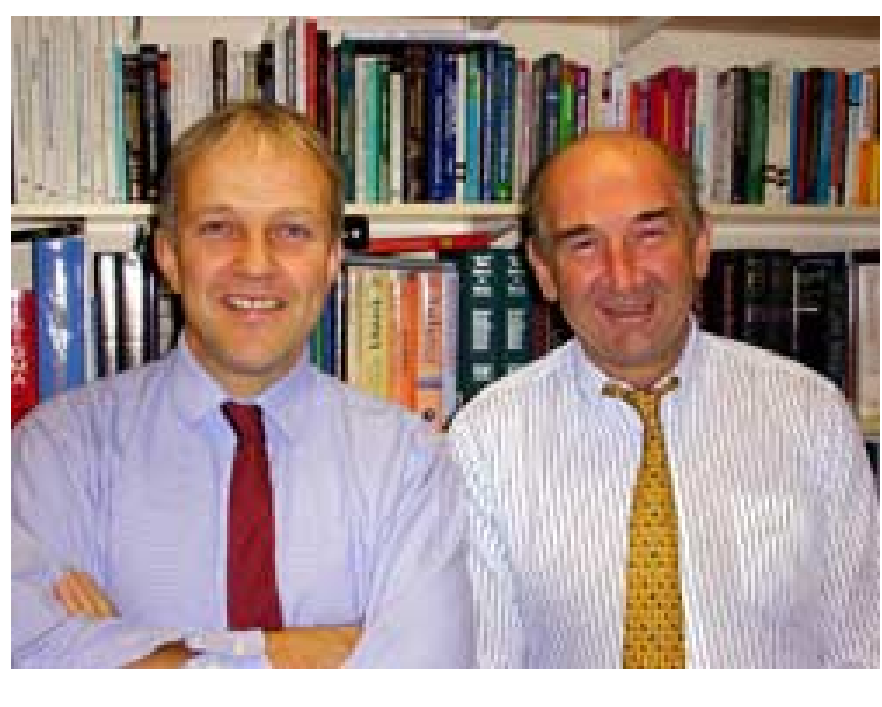

T.T.H. P.J.B.

to provide concise and highly condensed information. In this way we have tried to have specialists from the industry writing on their own fields of interest. This is a rapidly advancing field, and this format of segmented brief chapters has allowed us to put information on the internet, and should permit provision of regular updates.

The book has 14 sections that range from an introduction covering general aspects of drug development for asthma and COPD to a review of currently available small-molecular-weight synthetic medicinal chemical classes: bronchodilators, corticosteroids, anti-leukotrienes, and mediator and protease inhibitors. We then proceed from allergen and IgE-directed therapies to $\mathrm{T}$ cell immu- 
nomodulation and cytokine-directed therapy, to chemokine receptor and adhesion molecule inhibition, to therapy directed against cell signalling and transcription, before looking at future prospects for genetic therapy.

A considerable team has been involved in producing this volume, and we are very grateful for the vision of Chris Bolliger, Editor of Progress in Respiratory Research, who always wanted us to go for something 'completely different'! In addition, we have found the entire staff at
Karger Medical Publishers, Basel, a superbly professional group of people to interact with.

We hope that you will find this book interesting and helpful, and that it will give as much enjoyment to you, the reader, as we have had in its design and editing. Finally, and most importantly of all, we hope that this book will help in the process of finding better therapy for patients with allergic and respiratory diseases.

Trevor T. Hansel Peter J. Barnes 